\begin{tabular}{l|c|c} 
Journal of Social Studies Education Research & \\
Sosyal Bilgiler Eğitimi Araştırmaları Dergisi & 2017:8 (2), 178-190 & \\
\hline
\end{tabular}

\title{
Internationalization Impact on PhD Training Policy in Russia: Insights from The Comparative Document Analysis
}

\author{
Oksana Chigisheva $^{1}$, Elena Soltovets ${ }^{2}$, Anna Bondarenko $^{3}$
}

\begin{abstract}
The relevance of the study is due to the need for an objective picture of the Russian third level tertiary education transformation driven by internationalization issues and global trends in education. The article provides an analytical comparative review of the official documents related to the main phases of education reform in Russia and focuses on the system of $\mathrm{PhD}$ training which has undergone significant reorganization in recent years. A series of alterations introduced into the theory and practice of postgraduate education in Russia are traced in regulatory documents and interpreted in terms of growing internationalization demand. Possible implications for further development of the research human potential in Russia are being discussed. The method of comparative document analysis produces the best possible insight into the subject. The findings of the study contribute to the understanding of current challenges facing the system of doctoral studies in Russia and lead to certain conclusions on the transformation of educational policy in relation to $\mathrm{PhD}$ training under the influence of internationalization agenda.
\end{abstract}

Keywords: internationalization, educational policy, PhD training, comparative document analysis, Russia.

\section{Introduction}

Among the many trends shaping the face of modern higher education few are as powerful and tangible in their impacts as internationalization. The fact that internationalization of education has remained prominent on the global agenda is easily explainable taking into consideration the number of challenges it poses to national educational systems. One of the most obvious is connected with the by-effects of globalization. Accessibility and diversification of labour markets combined with the increased job and academic mobility stirred competition to an extent when "it is the market, not the state, that is the instrument for shaping educational values" (Ghosh, 2004, p. 93), spurring educational institutions into "interconnectedness and multi-level, multi-directional relationships" (Ghosh, 2004, p. 93) and bringing about the "culture of accountability" (Assessment in Education. Implications for Leadership, 2016, p. 28). Though the

\footnotetext{
${ }^{1}$ Assoc. Prof., Candidate of Pedagogy, Southern Federal University, opchigisheva@ @fedu.ru

2 Senior Lecturer, Southern Federal University, hsolt@mail.ru

${ }^{3}$ Master Student, Southern Federal University, anuta060693@mail.ru
} 
implications are far-reaching, it is the long-term vision that many higher educational establishments lack under the pressure of globalization, being prone, according to Mestenhauser (2002), to quick fixes in internationalization instead of developing a systematic approach. This constraint can be partly related to the institutional conservatism, which is seen by Ellingboe (1996) as one of the major barriers. Green (2003) mentions other institutional barriers manifested in "scarce resources, disciplinary paradigms, structures, or the absence of incentives" (Green, 2003, p. 1). The institutional level of changes fueled by internationalization also implies shifts in the attitudes of the university stakeholders (president, administration, faculty etc.) (Drascovic et al., 2017). Understanding them through the current policy and implementation efforts "is key in not only removing some of the barriers of the internationalization process, but also managing the university wide internationalization process effectively" (Iuspa, 2010, p. 50).

All the challenges mentioned are of special relevance for Russia that has been struggling its way through the higher education modernization process for the last two decades. In compliance with the European education integration process Russia has been gradually introducing alterations into its national education policy. The years after the adoption of the Bologna Process by the Russian Federation witnessed the process of "unification of educational standards with ones of the EU" being "the main trend in the development of Russian education" (Vorontsov \& Vorontsova, 2015, p. 1163). The changes took years, being introduced on the “bottom-up" principle into the Bachelors' level first with Masters' education to follow. Postgraduate education, therefore, was the last to undergo reforms. By that time the impacts of global processes were pervasive in terms of tertiary education internationalization. Whether the internationalization demands were met remains an open question.

The scope of meaning behind existing definitions of internationalization, as well as the variety of terms commonly used to address different aspects of internationalization, makes such assessment a difficult task. One of the recognized definitions proposed by the Association of International Educators (NAFSA, 2011) describes internationalization as the conscious effort to integrate and infuse international, intercultural, and global dimensions into the ethos and outcomes of postsecondary education. The definition of Jane Knight (2004) features it as a phenomenon more approachable in terms of national standards analysis, "the process of integrating international, intercultural and global dimensions into the purpose, functions teaching/learning, research and service - or delivery of higher education" (Knight, 2004, p. 9). 
She also suggests discriminating between "cross-border internationalization" for off-campus initiatives and "internationalization at home" for campus-based strategies including international and intercultural dimension in the teaching/learning process (Knight, 2010, p. 208). This research rests upon the "internationalization at home" assumption, as it enables a closer consideration of the country-specific standards of postgraduate education to the extent feasible. Thus, this study is aimed at revealing the extent of internationalization impact on $\mathrm{PhD}$ training policy in Russia. It seems possible to do it through rigorous comparative analysis of documents allowing fixing qualitative transformations in $\mathrm{PhD}$ educational domain in response to growing internationalization dynamics in the sector of Russian higher education.

\section{Literature Review}

A tremendous contribution to the study of the phenomenon of internationalization in higher education was made by Jane Knight, a renowned expert in the sphere. The definition proposed by Knight (2003) summarizes numerous concepts of internationalization as "the process of integrating an international, intercultural, or global dimension into the purpose, functions or delivery of postsecondary education" (Knight, 2003, p. 2).

The difference of internationalization strategies which are peculiar to the level of education (bachelor, master or doctorate) is repeatedly noted by Hans de Wit (2011). Considering the phenomenon of internationalization for higher education in his monograph of 2011, he also emphasizes the shift from "reactive to a pro-active strategic issue, from added value to mainstream" (de Wit, 2011, p. 232) as well as substantial change in its focus, scope and content. Complex relations between the "cross-border" and "home" internationalization are also examined; the fact that mobility is gradually being replaced from the centre stage by the issues of learning process and curriculum is seen as a current trend.

The significance of curricula internationalization has long been recognized by scholars and a lot has been said about acute necessity of globally competent educators (Kopish, 2016). Curricular change is shown as a "powerful and practical way to bridge the gap between rhetoric and practice" (Leask, 2001, p. 100). Advantages of the transformational approach, "which promotes a critical awareness of the bias and values inherent in Western pedagogical and curricular approaches' is described as able to minimize negative effects of various constraints (Williams, 2008, p. 32). A growing trend of internationalization in postsecondary education curricula is often interpreted in terms of dealing with foreign students' influx (James et al., 
2013). However, the "at home" internationalization is rarely considered as a set of national lawdriven alterations in the curriculum. While a wide range of national reports and country casestudies has been published recently (Butterfoeld, 2007; Leung et al., 2017), the reports on Russian experience published internationally are not plentiful.

The agenda of Soviet vs. post-Soviet dimensions fuels some of the research. Historical implications of the Soviet educational system collapse and academic internationalization in market-driven Russian reality are described by Kuraev (2014). Shaydorova (2014) provides the analysis of the rationales for internationalization of higher education taking into account interests of the main stakeholders.

One of the most comprehensive studies was conducted by the British Council, it covers the dimension of academic English language perspective (Frumina \& West, 2012). The prospects of further development of internationalization by higher educational institutions of Russia are viewed positively by Kulikova and Tseljutina (2015) who give a brief review of the forms of internationalization. The optimism is based on the continuing impact of globalization and integration trends on the educational environment resulting in enlarging the scope of forms and techniques enormously. On the contrary, Kupriyanova-Ashina and Chang (2013) stress the lack of strategic vision and the demand for system approach in shaping national educational concept in this respect. This view is shared by some Russian scholars. Thus, Filippov (2013) calls for creating a complex national policy document regulating internal internationalization in Russia. Knyazev and Drantusova (2013) study the models of institutional differentiation due to internationalization processes and present the analysis of the stakeholders' expectations as seen through the documental prism of government initiatives.

Finally, a far-reaching controversy is noticed by Kapshutar (2016) who studies a new Russian system of doctoral training, introduced after 2014, in terms of quality issues. It is a gap between the transformed status, process, normative legal base of doctoral programs and the rigidity of traditional approaches.

\section{Materials and Methods}

The paper draws upon data represented in the policy documents that include: 1. Law of the Russian Federation on Education N 3266-1 of July 10, 1992; 2. Federal Law on Education in the Russian Federation N 273-FL of December 29, 2012; 3. Decree of the Government of the Russian Federation No. 842 of September 24, 2013 (as amended on August 28, 2017) "On the 
procedure of awarding academic degrees" (together with the "Regulation on awarding academic degrees"). (2013); 4. Decree from July 30, 2014 N 902 on the "Approval of the Federal State Educational Standards of Higher Education, Field of Studies 44.06.01 Education and Pedagogical Sciences (highly qualified personnel training level)” (2014); 5. Order from July 30, 2014 N 902 on the "Approval of the Federal State Educational Standards of Higher Education, Field of Studies 44.06.01 Education and Pedagogical Sciences (highly qualified personnel training level)" (2014); 6. Order of the Ministry of Education and Science of the Russian Federation of March 18, 2016 N 227 "On approval of the procedure for conducting state final certification on educational programs of higher education - programs for the training of scientific and pedagogical staff in postgraduate study, traineeship, internship programs" (2016); 7. Federal Law "On Amendments to Article 4 of the Federal Law "On Science and State Policy in Science and Technology" of May 23, 2016, N 148-FL (2016).

Document analysis was used for systematic and thorough review and evaluation of the chosen educational policy documents that have been regulating $\mathrm{PhD}$ training at different time periods in Russia (Bowen, 2009). The research was supported by the comparative method (Phillips \& Schweisfurth, 2014, Fedotova \& Chigisheva, 2015) that allowed to highlight the key changes associated with internationalization process taking into account worldwide trends in the sphere of higher education and doctoral studies.

\section{Results and Discussion}

The collapse of the Soviet Union brought about the transformation of the whole system of higher education. The pattern of doctoral students' training also had to undergo a number of reforms in compliance with the new national policy in the field of tertiary education of the young Russian Federation. Its fundamental principles were provided by the Law of the Russian Federation on Education N 3266-1 of July 10, 1992. According to the Law, in the post-Soviet tertiary education system postgraduate professional education was the basic form of training academic and teaching staff (academics) as well as researchers.

The process of the doctoral training transformation was driven by a complex system of interlinked factors. Unlike the Soviet education tradition, which, as a number of scholars have noted, had remained "frozen internally" in its theories and practices and had been "impervious to outside influences" seen as a threat (Morgan \& Kliucharev, 2012, p. 3), the newly-born Russian education was sensitive to the world-wide trends. As Russia was striving for international 
cooperation, the post-Soviet education was characterized by the increasing integration processes. Some radical transformations were dictated by "both internal social and economic needs and external pressures such as Europeanisation and globalization" (Morgan \& Kliucharev, 2012, p. 5). As Gounko and Smale (2007) point out, "the most notable changes in higher education were achieved through curriculum reform, institutional autonomy, the diversification and expansion of higher education and the introduction of tuition fees in public institutions" (Gounko \& Smale, 2007, p. 533).

The biggest impact on modernization of the doctoral students' training process was clearly related to the EU Bologna Process, joined by Russia in 2003. Communiqué of the Conference of Ministers responsible for Higher Education in Berlin on 19 September 2003. "Realising the European Higher Education Area" spotlighted the doctoral level of higher education and emphasized the necessity to include it into the Bologna Process as a third-pillar of higher education. The Bologna Process prescribed a transfer from the classical pattern of doctoral students training within its system/paradigm of "research student - scientific advisor" relations to the well-structured doctoral program as the third cycle. The latter relies on a comprehensive syllabus involving thesis research (compulsory for all learners of the program), in-depth disciplinary and interdisciplinary training (provided through a series of seminars, courses and workshops), as well as educational modules aimed at developing profession-related competencies (Bedny, 2013). Quite expectedly Russia "had a long way to go in terms of adaptation and pilots" (Esyutina et al., 2013, p. 152). It was not until 2011 when large-scale educational reforms resulted in meaningful curricula changes. Fundamental changes in the system of postgraduate training were soon to follow. The Federal Law on Education in the Russian Federation N 273-FL of December 29, 2012 proclaimed a shift from postgraduate vocational education to doctoral study programs as the third cycle of higher education. This new model was supposed to change the status of postgraduate education as a social institution, its aims and functions as well as the training and assessment procedure, but started to actually function only two years later, in 2014 (Bedny, 2017, p. 6).

Training programs for research students had to abide by the Federal State Educational Standard of Higher Education approved in 2014 by the Order N 902 of the Ministry of Education and Science of the Russian Federation. The doctoral study program is expected to equip the students with all necessary competences for carrying out research in a certain professional area 
and teaching activity in higher education institutions (Order from July 30, 2014 N 902 on the "Approval of the Federal State Educational Standards of Higher Education, Field of Studies 44.06.01 Education and Pedagogical Sciences (highly qualified personnel training level)" (2014).

The Law specifies the procedure of the end-of-course assessment as including the following forms:

- state examination;

- defending graduate qualification thesis;

- scientific report on the main results of the research graduate qualification work (dissertation) (Order of the Ministry of Education and Science of the Russian Federation of March 18, 2016 N 227 “On approval of the procedure for conducting state final certification on educational programs of higher education - programs for the training of scientific and pedagogical staff in postgraduate study, traineeship, internship programs", 2016).

Thorough and comprehensive as it may seem, the assessment procedure did not lead to a scientific degree. The requirements for conferment of science degree were specified by the Decree of the Government of the Russian Federation No. 842 "On the procedure of awarding academic degrees" (together with the "Regulation on awarding academic degrees") (2013). A public defense of a thesis is still a prerequisite for being awarded a Candidate of Science degree (Soviet equivalent of the second level science degree). The Candidate of Science Diploma/Certificate is granted by the institution where the thesis is defended. The decision is made by the Dissertation Board of the institution and finally by the Higher Attestation Commission of the Russian Federation.

On May, 23, 2016 the Government of the Russian Federation approved the Federal Law "On Amendments to Article 4 of the Federal Law "On Science and State Policy in Science and Technology" (2016) which granted two leading Russian universities (Moscow State University and Saint Petersburg State University) autonomy in decision making and degrees conferring. The following phase began on September, 1, 2017, when the list of the institutions enjoying the right to confer degrees was extended up to 20. This is a direct acknowledgement of international experience regarding lack of state control in degree confirmation and transfer of this function directly to the universities. 


\section{Conclusion}

General analysis of the most fundamental changes manifested in the documents regulating national educational environment has revealed a number of trends that can be interpreted as positive in terms of internationalization of the third stage tertiary education in Russia. Comparative analysis of selected legislative documents within the period of 1992-2016 has demonstrated a gradual shift in the focus of educational policy, urged by the Bologna Process and enshrined in the Federal Law on Education in the Russian Federation of 2012. This led to further legislation initiatives standardizing various aspects of educational reform as to its procedure, requirements and the expected results.

The practice-oriented character of the learning process is another trend evidenced through the educational theory documents review. The transformation process involves all levels from terminology through the scope of educational approaches used to the teaching techniques. The bulk of changes within the analyzed period indicate a clear emphasis on competitiveness as the idea underlying the process of doctoral training in Russia.

Analysis of the documents regulating the teaching practice and final certification has confirmed a strong positive relationship between the progress of the third level higher education in Russia and new requirements imposed on both parties of the learning-teaching process. The whole picture reveals a general tendency towards international transparency: a capacity for selfdevelopment and establishing oneself at the global research labour market is interpreted as a key factor for professional development.

Most evidently the positive trends have been traced in the Federal State Educational Standards of Higher Education reshaping the post-graduate studies' curriculum. Enlargement and diversification of the number of disciplines studied, the stress on intensification of the researchspecific competencies development and introduction of English as an equal-partner language signal a clear recognition of the key role of the third-level training for the global research career development.

The process of the $\mathrm{PhD}$ training reforms in Russia is far from being successfully completed. However, it allows some cautious optimism, as the tendency towards orientation on educational internationalization remains relevant for Russian postgraduate education of 2017. 


\section{Acknowledgements}

The research was supported by the Russian Foundation for Basic Research grant N 1736-01125 "Functional Literacy of Highly Qualified Scientific and Pedagogical Personnel in Russia and the UK: Outcomes of the International Comparative Study”.

\section{References}

Assessment in Education. Implications for Leadership (2016). Scott, S., Scott, D.E., Webber, C.F. (Eds.). XIV, Springer.

Bedny, B.I. (2013). The role and structure of educational training in the new-generation postgraduate studies. Higher Education in Russia, 12, 78-89.

Bowen, G.A. (2009). Documentary Analysis as a Qualitative Research Method. Qualitative Research Journal, 9(2), 27-40.

Butterfoeld, A. (2007). The Internationalization of Doctoral Social Work Education: Learning from a Partnership in Ethiopia. Advances in Social Work, 8(2), 237-251.

Communiqué of the Conference of Ministers responsible for Higher Education in Berlin on 19 September 2003. Realising the European Higher Education Area. (2003). URL: https://media.ehea.info/file/2003_Berlin/28/4/2003_Berlin_Communique_English_577284. pdf

de Wit, H. (2011). Globalisation and Internationalization of Higher Education" [introduction to online monograph]. Revista de Universidad y Sociedad del Conocimiento (RUSC), 8(2), 241-248.

Decree from July 30, 2014 N 902 on the "Approval of the Federal State Educational Standards of Higher Education, Field of Studies 44.06.01 Education and Pedagogical Sciences (highly qualified personnel training level)"(2014). URL:

http://fgosvo.ru/uploadfiles/fgosvoaspism/440601.pdf

Decree of the Government of the Russian Federation No. 842 of September 24, 2013 (as amended on August 28, 2017) "On the procedure of awarding academic degrees" (together with the "Regulation on awarding academic degrees"). (2013). URL: http://wWw.consultant.ru/document/cons_doc_LAW_152458/

Draskovic, M., Milica, D., Mladen, I. \& Chigisheva, O. (2017). Preference of institutional changes in social and economic development. Journal of International Studies, Vol. 10, N. 2, 318-328. 
Ellingboe, B.J. (1996). Divisional Strategies on Internationalizing the Curriculum: A Comparative, Five-College Case Study of Deans' and Faculty Perspectives at the University of Minnesota. Master of Arts Thesis, University of Minnesota.

Esyutina, M., Fearon, C. \& Leatherbarrow, N. (2013). The Bologna process in higher education: An exploratory case study in a Russian context. Quality Assurance in Education, 21(2), 145-161.

Federal Law "On Amendments to Article 4 of the Federal Law "On Science and State Policy in Science and Technology" of May 23, 2016, N 148-FL (2016). URL: http://www.consultant.ru/document/cons_doc_LAW_152458/

Federal Law on Education in the Russian Federation N 273-FL of December 29, 2012. (2012). URL: http://base.garant.ru/70291362/

Fedotova, O. \& Chigisheva, O. (2015). Comparative analysis: Methodological optics in the ideological context. International Perspectives on Education and Society, Vol. 26, 57-82.

Filippov, V.M. (2013). Internal internationlization of higher education in Russia. In: Rationales for internationalization, Larionova, M., Perfilieva, O. (Eds.). Moscow: Logos Publishing House, 200-211.

Frumina, E. \& West, R. (2012). Internationalization of Russian higher education: the English language dimension. British Council. URL:

https://www.britishcouncil.ru/sites/default/files/internationalisation_of_russian_higher_edu cation.pdf

Ghosh, R. (2004). Globalization in the North American region: Toward renegotiation of cultural space. McGill Journal of Education, 39(1), 87-101.

Gounko, T. \& Smale, W. (2007). Modernization of Russian higher education: exploring paths of influence. Compare: A Journal of Comparative and International Education, 37(4), 533 548.

Green, M. (2003). The challenge of internationalizing undergraduate education: Global learning for all. Paper presented at the Duke University's Global Challenges and U.S. Higher Education Conference. Durham, NC.

Iuspa, F.E. (2010). Assessing the Effectiveness of the Internationalization Process in Higher Education Institutions: A Case Study of Florida International University. FIU Electronic Theses and Dissertations. URL: http://digitalcommons.fiu.edu/etd/316 
James, C.E., Cullinan C.C. \& Abdi A.A. (2013). Internationalizing Postsecondary Education. In: Critical Perspectives on International Education. Comparative and International Education (A Diversity of Voices), Hébert Y., Abdi A.A. (Eds.), Vol. 15. Rotterdam: Sense Publishers.

Kapshutar, M.A. (2016). The quality of doctoral students' training and the efficiency of the modern post-graduate education: searching for the new indices. Modern KnowledgeIntensive Technologies, 7(1), 132-136.

Knight, J. (2004). Internationalisation Remolded: Rationales, Strategies and Apoproaches. Journal for Studies in International Education, 8(1), 5-31.

Knight, J. (2010). Internationalisation and the Competitiveness Agenda. In: Higher Education, Policy, and the Global Competition Phenomenon. Portnoi, L.M., Rust, V.D., Bagley, S.S. (Eds.). New York: PALGRAVE MACMILLAN, 205-218.

Knight, J. (2003). Updated internationalization definition. International Higher Education, 33, 23.

Knyazev, E.A. \& Drantusova, N.V. (2013). To the question on linkage between internationalization and institutional diversity in the systems of higher education. In: Larionova, M., Perfilieva, O. (Eds.). Rationales for internationalization. Moscow: Logos Publishing House, 215-243.

Kopish, M.A. (2016). Preparing Globally Competent Teacher Candidates Through CrossCultural Experiential Learning. Journal of Social Studies Education Research, 7(2), 75108.

Kulikova O.V.\& Tseljutina T.V. (2015). The prospects of higher education internationalization development. Fundamental Studies, 7-8, 610-614.

Kupriyanova-Ashina, V. \& Chang Zh. (2013). The internationalization of higher education: The Russian Approach. International Trends. Journal of International Relations Theory and World Politics, 11, 2(33), 85-94.

Kuraev, A. (2014). Internationalization of Higher Education in Russia: Collapse or Perpetuation of the Soviet System? A Historical and Conceptual Study, PhD, Boston College. URL: http://hdl.handle.net/2345/3799

Law of the Russian Federation on Education N 3266-1 of July 10, 1992. (1992). URL: http://en.russia.edu.ru/information/npb/fzakon/law/3266-1/index,3/ 
Leask, B. (2001). Bridging the gap: Internationalizing university curricula. Journal of Studies in International Education, 5(2), 100-115.

Leung, D, Carlson, E, Kwong, E.E.Y., Idvall, E. \& Kumlien, C. (2017). Exploring research cultures through internationalization at home for doctoral students in Hong Kong and Sweden. Nursing \& Health Sciences. URL: https://doi.org/10.1111/nhs.12369

Mestenhauser, J. (2002). In search of a comprehensive approach to international education: a systems perspective. In: Rockin'in Red Square: Critical approaches to international education in the age of cyberculture. Grunzweig, W., Rinehart, N. (Eds.). London: Vit Verlag, 165-202.

Morgan, W.J. \& Kliucharev, G.A. (2012). Higher Education and the Post-Soviet Transition in Russia. European Journal of Education, 47(1), 3-8.

NAFSA's Contribution to Internationalization of Higher Education (2011). URL: https://www.nafsa.org//File//2011_izn_contributions.pdf

Order from July 30, 2014 N 902 on the "Approval of the Federal State Educational Standards of Higher Education, Field of Studies 44.06.01 Education and Pedagogical Sciences (highly qualified personnel training level)" (2014). URL: http://fgosvo.ru/uploadfiles/fgosvoaspism/440601.pdf

Order of the Ministry of Education and Science of the Russian Federation of March 18, $2016 \mathrm{~N}$ 227 "On approval of the procedure for conducting state final certification on educational programs of higher education - programs for the training of scientific and pedagogical staff in postgraduate study, traineeship, internship programs". (2016). URL: http://www.consultant.ru/document/cons_doc_LAW_196763/49224697548ccd20b77f1c40 aa5682e985c6134e/

Phillips D. \& Schweisfurth, M. (2014). Comparative and International Education. An Introduction to Theory, Method, and Practice. London, Bloomsbury: Continuum International Publishing Group.

Shaydorova, G. (2014). Rationales for the internationalization of higher education: the case of Russia. URL: https://tampub.uta.fi/handle/10024/96033

Vorontsov, A. \& Vorontsova, E. (2015). Current Trends in Russian Scientific and Educational Development in the Context of Worldwide Globalization. Procedia - Social and Behavioral Sciences, 214, 1156-1164. 
Williams, S. (2008). Internationalization of the Curriculum: A Remedy for International Students' Academic Adjustment Difficulties? Memorial University of Newfoundland. URL:

http://web.uvic.ca/ sherriw/images/ED\%206890\%20Sherri\%20Williams\%20Final\%20Pap er\%20for\%20website.pdf 